\title{
Length-weight Relationships and Condition Factor of Chub (Squalius cephalus, Linnaeus, 1758) from the Area of Northeastern Bosnia and Herzegovina
}

\author{
Eldar Tanović ${ }^{1}$, Edina Hajdarević ${ }^{2}$, Avdul Adrović ${ }^{2}$, Isat Skenderović ${ }^{2}$, \\ Alen Bajrić ${ }^{2}$, Amela Tanović ${ }^{3}$ \\ ${ }^{1}$ Coal mine "Kreka", Mije Keroševića 1, 75000, Tuzla, Bosnia and Herzegovina \\ ${ }^{2}$ University of Tuzla, Faculty of Natural Sciences and Mathematics, Department of Biology, \\ Urfeta Vejzagića 4, 75000, Tuzla, Bosnia and Herzegovina \\ ${ }^{3}$ University of Tuzla, Faculty of Technology, Department of Agronomy, Urfeta Vejzagića 8, \\ 75000, Tuzla, Bosnia and Herzegovina
}

\begin{abstract}
The aim of this research is the analysis of the length-weight relationships and the condition factor of chub (Squalius cephalus L.) from certain rivers in northeastern Bosnia and Herzegovina that belong to the Black Sea basin. The research was conducted on 200 specimens of chub (Squalius cephalus L.) during 2019. The estimated values of the total body length ranged from $10.06 \mathrm{~cm}$ to $29.33 \mathrm{~cm}$, with the mean body length of $15.97 \mathrm{~cm}$ in the total sample. The fish weight ranged from $8.0 \mathrm{~g}$ to $264.5 \mathrm{~g}$, with the mean value of $46.8 \mathrm{~g}$. The length-weight relationships of chub were determined in relation to their age classes. The fish in age classes $1+, 4+$ and $5+$ indicate a positive allometric growth $(b>3)$, while the fish in age classes $2+$ and $3+$ have a negative allometric growth $(b<3)$. The analysis of the coefficient of determination, $\mathbf{R}^{2}$, shows that the fish in age classes $1+i 4+$ have the highest values of this coefficient $(>0,9)$.
\end{abstract}

DOI: 10.18421/TEM111-20

https://doi.org/10.18421/TEM111-20

Corresponding author: Eldar Tanović,

Coal mine "Kreka", Mije Keroševića 1, 75000, Tuzla,

Bosnia and Herzegovina.

Email: eldartana@gmail.com

Received: 01 November 2021.

Revised: 04 December 2021.

Accepted: 26 December 2021.

Published: 28 February 2022.

(cc)BY-NC-ND(C) 2022 Eldar Tanović et al; published by UIKTEN. This work is licensed under the Creative Commons Attribution-NonCommercial-NoDerivs 4.0 License.

The article is published with Open Access at www.temjournal.com
ANOVA analysis of the condition factor of chub based on age classes indicates that there are no statistically significant differences in the distribution of this factor between the fish of the same age classes from different localities $(P<\mathbf{0 . 0 5})$.

Keywords - length-weight relationships, condition, Squalius cephalus, northeastern Bosnia.

\section{Introduction}

The studies on the chub population in the rivers of northeastern Bosnia are of great scientific and ecological significance due to the fact that this fish species inhabits the mentioned watercourses in a high percentage. The analysis is also significant from the standpoint of the effect of different anthropogenic factors on fish populations, which is reflected by the artificial changes in the ecosystem in which they live. One of the ways of monitoring the effects of different factors on fish populations is monitoring the lengthweight relationships. Through monitoring these relationships, it is possible to determine the health condition of fish populations. In addition to studying these characteristics, studies on their meristic and behavioral traits offer significant information on fish populations [1]. Any management strategy that aims to safeguard biodiversity can be successful only if it is based on a thorough awareness of the diffusion, ecology and biology of the fish species [2], [3]. The chub (Squalius cephalus) is an opportunistic and mobile species and is common in all running waters in Europe [4]. The range of its distribution is from Ural to the north of Spain and from the south of Sweden to Italy [5]. In the waters of Bosnia and Herzegovina, this species occurs in all the watercourses of the Black Sea basin [6]. 


\section{Materials and Methods}

For the research purpose, during 2019, 200 individuals of chub (Squalius cephalus, Linnaeus, 1758) of different age classes were collected from 10 localities in northeastern Bosnia and Herzegovina. They were caught from the following rivers: Spreča, Gostelja, Turija, Suha, Tinja, Jala, Sapna, Brka, Oskova and Bosna (Figure 1).

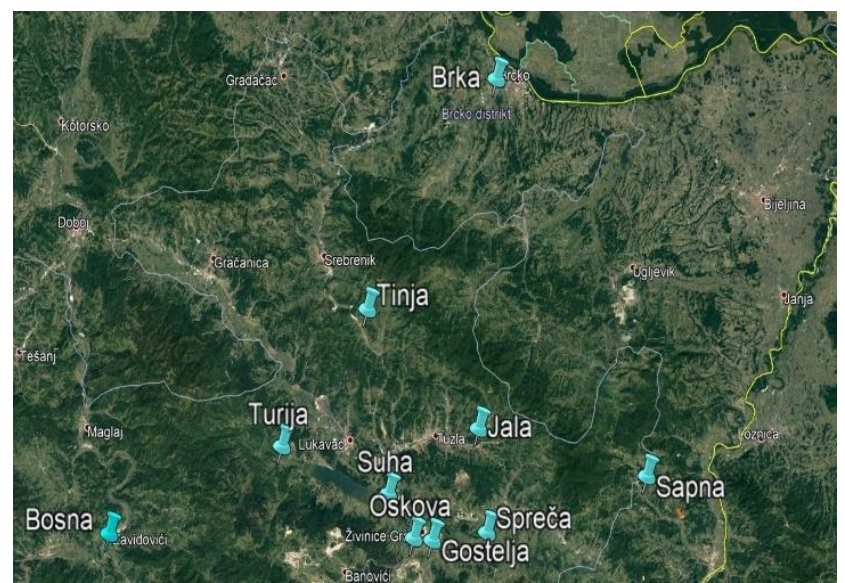

Figure 1. Location map of the investigated site (Google Earth)

The specimens were fished using the electric inverter SUSAN 735. Then, the individuals were photographed for a geometric analysis, their weight was measured and they were stored in a $4 \%$ formaldehyde solution.

The total body length determined from the photographs of the specimens was used for the purpose of calculating the length-weight relationships and the condition factor, via the TPS series of software and software tool Tmorph Gen.

The length-weight relationship was calculated applying the following formula :

$$
\mathrm{W}=\mathrm{aL}^{\mathrm{b}}
$$

A measure of the proportion of the variation of the specimens' weight (W) determined by the variation of their standard length (L) is expressed by the coefficient of determination $\mathrm{R}^{2}$

The condition factor was calculated using the formula $\mathrm{CF}=(\mathrm{W} \times 100) /(\mathrm{L})^{3}$

Age was determined using scale reading. Scales were taken from the middle of the body, behind the pectoral fins and above the lateral line.

\section{Results}

In the present study, the age of 200 individuals of $S$. cephalus caught from different rivers of northeastern Bosnia and Herzegovina ranged between $0+$ to $5+$ years and among the different age classes, the second and the third year classes were dominant (Table 1). The least represented were the individuals of age class $0+$ (one individual), so it was not taken into further consideration.

Table 1. The sample representation from the analyzed rivers by age classes

\begin{tabular}{l|cccccc}
\multicolumn{1}{r}{$\begin{array}{l}\text { Age } \\
\text { Spreča }\end{array}$} & $\mathbf{0 +}$ & $\mathbf{1 +}$ & $\mathbf{2 +}$ & $\mathbf{3 +}$ & $\mathbf{4 +}$ & $\mathbf{5 +}$ \\
\hline Turija & $/$ & 2 & 7 & 11 & $/$ & $/$ \\
Suha & 1 & 5 & 10 & 6 & $/$ & $/$ \\
Oskova & $/$ & 2 & 8 & 10 & $/$ & $/$ \\
Brka & $/$ & 1 & 6 & 9 & 4 & $/$ \\
Gostelja & $/$ & $/$ & 7 & 13 & $/$ & $/$ \\
Tinja & $/$ & $/$ & 13 & 6 & 1 & $/$ \\
Jala & $/$ & $/$ & 2 & 8 & 10 & $/$ \\
Sapna & $/$ & $/$ & 12 & 8 & $/$ & $/$ \\
Bosna & $/$ & $/$ & $/$ & 12 & 4 & 4 \\
$\quad$ & $\mathbf{\Sigma}$ & $\mathbf{1 2}$ & $\mathbf{7 7}$ & $\mathbf{8 7}$ & $\mathbf{1 9}$ & $\mathbf{4}$
\end{tabular}

The maximum individual length was recorded in the chub individual from the Jala River $(29.33 \mathrm{~cm})$, while the minimum individual length was from the

Suha River $(10.06 \mathrm{~cm})$. The mean length of the analyzed individuals was $15.97 \mathrm{~cm}$. The maximum individual weight was also recorded in the chub individual from the Jala River (264.5 g), while the minimum individual weight was measured in the individual from the Suha River $(8.0 \mathrm{~g})$. The mean weight of the total sample was $46.80 \mathrm{~g}$. The mean values of the total length and weight of the individuals by localities are shown in Table 2 .

Table 2. The mean values of the total length and weight of the individuals by localities

\begin{tabular}{|c|c|c|}
\hline & $T L(\mathrm{~cm})$ & $W(g)$ \\
\hline Bosna & 21.42 & 106.58 \\
\hline Brka & 17.97 & 62.87 \\
\hline Oskova & 17.86 & 62.91 \\
\hline Sapna & 13.23 & 21.35 \\
\hline Jala & 18.18 & 64.61 \\
\hline Tinja & 16.46 & 42.36 \\
\hline Suha & 12.09 & 16.98 \\
\hline Turija & 12.50 & 19.96 \\
\hline Gostelja & 14.66 & 32.90 \\
\hline Sprě̌a & 15.33 & 37.49 \\
\hline
\end{tabular}

\subsection{Length-weight relationships}

By calculating the length-weight relationships of chub of age class $1+$, it has been determined that they have a positive allometric growth; that is, they are characterized by values of the coefficient of regression $b=3,2809$ and the coefficient of determination $R^{2}=0,9839$ (Figure 2). 


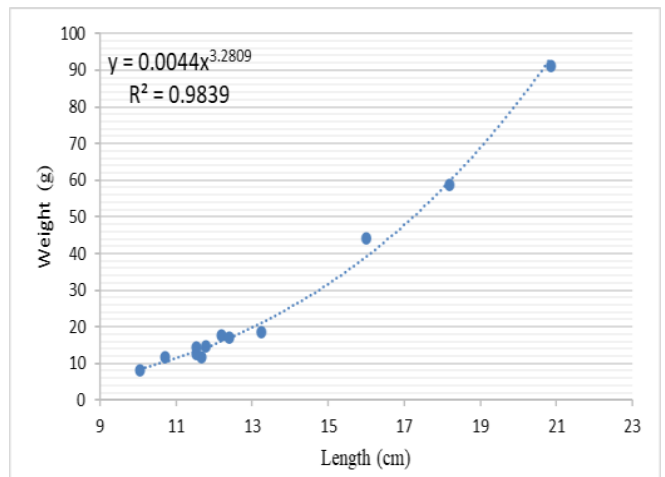

Figure 2. Length-weight relationships of chub of age class $1+$

Age classes $2+$ i $3+$ indicate negative allometric growth, given that the analysis determined the coefficient of regression less than 3 . In fact, chub individuals of age class $2+$ are characterized by values of the coefficient of regression $b=2,8622$ and the coefficient of determination $\mathrm{R}^{2}=0,8516$ (Figure $3)$.

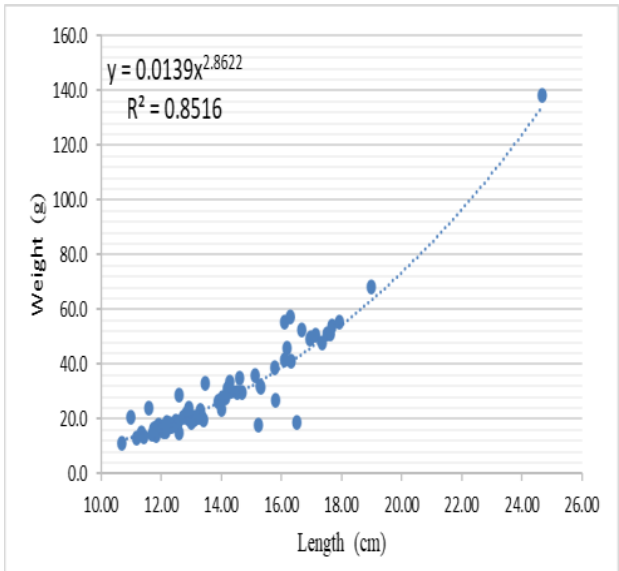

Figure 3. Length-weight relationships of chub of age class $2+$

Chub individuals of age class $3+$ are characterized by values of the coefficient of regression $b=2.5618$ and the coefficient of determination $\mathrm{R}^{2}=0.7055$ (Figure 4).

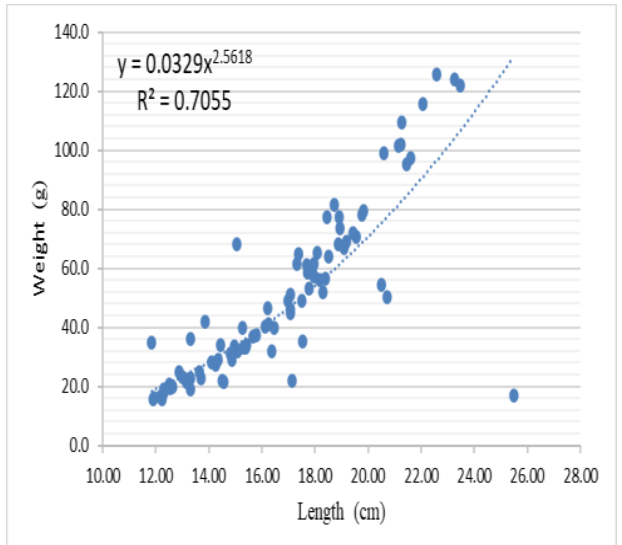

Figure 4. Length-weight relationships of chub of age class $3+$
Age class 4+ indicates positive allometric growth, with values of the coefficient of regression $b=$ 3,0801 and the coefficient of determination $\mathrm{R}^{2}=$ 0,9547 (Figure 5).

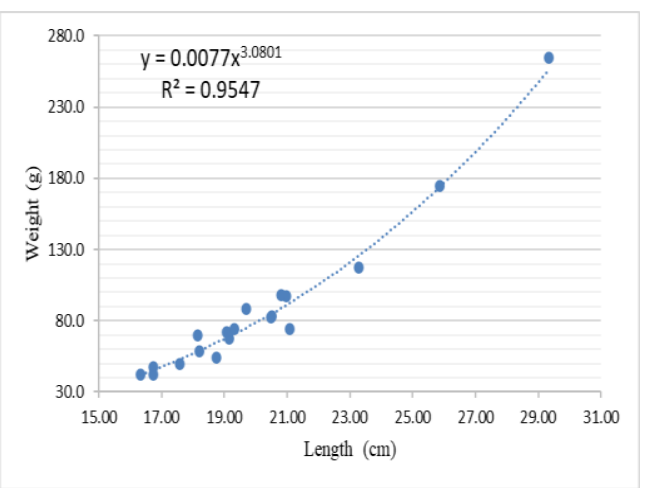

Figure 5. Length-weight relationships of chub of age class $4+$

Moreover, age class 5+ is characterized by positive allometric growth with values of the coefficient of regression $b=6,4501$ and the coefficient of determination $\mathrm{R}^{2}=0,621$ (Figure 6).

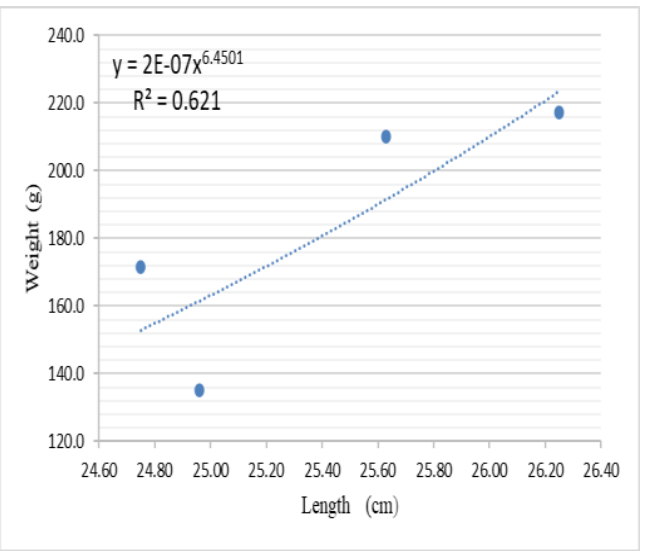

Figure 6. Length-weight relationships of chub of age class $5+$

\subsection{Condition Factor}

The determined values of the condition factor for individuals of all the age classes ranged from 0.908 in individuals of age class $1+$ to 1.112 in individuals of age class $5+$ (Table 3 ).

Table 3. Values of the condition factor by age classes

\begin{tabular}{cc}
\hline Age class & Condition factor(CF) \\
\hline $\mathbf{1 +}$ & 0.908 \\
$\mathbf{2 +}$ & 0.982 \\
$\mathbf{3 +}$ & 0.999 \\
$\mathbf{4 +}$ & 0.988 \\
$\mathbf{5 +}$ & 1.112 \\
\hline
\end{tabular}

The one-factor ANOVA analysis has been conducted to determine whether there is a statistically significant difference in values of the 
condition factor in individuals of the same age class but from different localities. According to the results of this analysis, there are no statistically significant differences in the condition factor between individuals of the same age class from different localities $(\mathrm{P}>0,05)$, considering that all the individuals that belong to age class $5+$ were fished out of the Bosna River so the analysis for this age class has not been done.

\section{Discussion}

In the analyzed chub specimens fished in the rivers of northeastern Bosnia and Herzegovina, values of the total length ranging from $10.06 \mathrm{~cm}$ to $29.33 \mathrm{~cm}$ (Ave: $15.97 \mathrm{~cm}$ ) were determined. The weight of the caught fish ranged from 8.0g to $264.5 \mathrm{~g}$ (Ave: 46.46 g). The condition factor values ranged from 0.908 to 1.112 and the mean value was 0.9978 .

The age of the individuals from the Gamasiab River of the Hamadan Province in Iran ranged from 1 to 4 years, while their length ranged from 13.83 to $29.51 \mathrm{~cm}$ and the body weight from 31.4 to $271.12 \mathrm{~g}$ [3]. In the mentioned study, the length-weight relationship showed a positive allometric growth for average total species as $b=3,97$ with the coefficient of determination $\mathrm{R}^{2}=0,97$, while the mean condition factor was $875 \mathrm{~g} / \mathrm{cm}$. A negative allometric growth has been determined in individuals of both sexes from the Ikizcetepeler Dam Lake, with values in males $b=2,92$, and in females $b=2,87$, while the coefficient of determination in both sexes was $\mathrm{R}^{2}=$ 0,90 [9]. Benzer [10], by analyzing the length-weight relationships of chub from Kirmir stream of the Sakarya River, Turkey, has determined that both sexes indicate a positive allometric growth $(b=3,06)$ with the coefficient of determination $\mathrm{R}^{2}=0.900$ in males and $\mathrm{R}^{2}=0.915$ in females.

Vlach et al. [11], in the individuals of chub (Leuciscus cephalus) from Úpoř Stream, have observed a positive allometric growth with values of the coefficient of regression $b=3.0667$ and the coefficient of determination $\mathrm{R}^{2}=0.96$.

In the studies conducted by Treer et al. [12] in the Dobra and Kupa rivers, the individuals of different age classes showed a positive allometric growth, while in the Bednja Lika and Lonja rivers a negative allometric growth was noted. The individuals of different age classes from all the localities showed different values of the condition factor, which ranged from 0.78 to 1.52 (Table 4).

Bajrić et al., [13] analyzed the age and growth of chub from 14 localities in northeastern Bosnia and concluded that the investigated sample showed a positive allometric growth $(\mathrm{b}>3)$.

The condition factor in this study ranged from 0.908 in the individuals of age class $1+$ to 1.11205 in the individuals of age class 5+. The one-factor ANOVA analysis indicates that there are no statistically significant differences regarding the condition factor between the individuals from different localities that belong to the same age classes ( $P>0,05)$. The obtained results are similar to the results of this study.

The average condition factor of chub from Úpoř stream reached the value 1.49 [11], which is higher in comparison to the values obtained during this study. Koç et al. [9], in their study of chub in the Ikizcetepeler Lake state that the mean condition factor for females was higher than that for males, but the differences between sexes were not significant $(\mathrm{P}$ $>0.05$ ).

Statistically significant differences related to the condition factor between sexes and different age classes were not observed in chub from Kirmir Stream of the Sakarya River, $(\mathrm{P}>0.05)[10]$.

Bajric et al., [13] conclude that, in the studies on chub populations, the mean values of the condition factor have increasing values in relation to the body length by age classes. In the male individuals, an increase of the condition factor was observed as the age increased, while in the female individuals this factor was highest in age class $2+$. In age class 1+, values for this factor were equal; a higher condition factor in age class $2+$ was determined in females, while the condition factor in age class $3+$ was higher in males.

Table 4. Comparative representation of the results of the conducted research and literature data

\begin{tabular}{|c|c|c|c|c|}
\hline Locality & $\begin{array}{c}\text { Age } \\
\text { class/sex }\end{array}$ & $\mathrm{CF}$ & b & $\mathbf{R}^{2}$ \\
\hline \multirow{5}{*}{$\begin{array}{l}\text { Northeastern } \\
\text { Bosnia (this } \\
\text { research) }\end{array}$} & $1+$ & 0.908 & 3.2809 & 0.9839 \\
\hline & $2+$ & 0.982 & 2.8622 & 0.8516 \\
\hline & $3+$ & 0.999 & 2.5618 & 0.7055 \\
\hline & $4+$ & 0.988 & 3.0801 & 0.9547 \\
\hline & $5+$ & 1.112 & 6.4501 & 0.621 \\
\hline $\begin{array}{c}\text { Gamasiab } \\
\text { (Sedaghat et al., } \\
\text { 2012) }\end{array}$ & $1-4$ & 875 & 3.97 & 0.97 \\
\hline \multirow{2}{*}{$\begin{array}{c}\text { Ikizcetepeler } \\
\text { (Koç et al. } \\
\text { 2006) }\end{array}$} & $\mathrm{m}$ & $\begin{array}{l}1.01- \\
3.04\end{array}$ & 2,92 & 0.90 \\
\hline & $\mathrm{f}$ & $\begin{array}{l}1.01- \\
3.05\end{array}$ & 2.87 & 0.90 \\
\hline \multirow{2}{*}{$\begin{array}{c}\text { Kirmir Stream } \\
\text { of Sakarya } \\
\text { River (Benzer, } \\
\text { 2013) }\end{array}$} & $\mathrm{m}$ & $\begin{array}{l}1.05- \\
2.33\end{array}$ & 3.06 & 0.900 \\
\hline & $\mathrm{f}$ & $\begin{array}{l}1.05- \\
2.73\end{array}$ & 3.06 & 0.915 \\
\hline $\begin{array}{c}\text { Úpoř } \\
\text { (Vlach et al., } \\
\text { 2005) }\end{array}$ & $1-9$ & I & 3.0667 & 0.96 \\
\hline \multirow{4}{*}{$\begin{array}{c}\text { Dobra } \\
\text { (Treer et al. } \\
\text { 1999) }\end{array}$} & $0+$ & 0.78 & \multirow{4}{*}{3.369} & \multirow{4}{*}{ I } \\
\hline & $1+$ & 0.89 & & \\
\hline & $2+$ & 1.08 & & \\
\hline & $3+$ & 1.13 & & \\
\hline
\end{tabular}




\begin{tabular}{|c|c|c|c|c|}
\hline & $4+$ & 1.19 & & \\
\hline & $5+$ & 1.28 & & \\
\hline & $6+$ & 1.23 & & \\
\hline \multirow{8}{*}{$\begin{array}{c}\text { Bednja } \\
\text { (Treer et al. } \\
\text { 1999) }\end{array}$} & $0+$ & 1.52 & \multirow{8}{*}{2.872} & \multirow{8}{*}{ I } \\
\hline & $1+$ & 1.34 & & \\
\hline & $2+$ & 1.23 & & \\
\hline & $3+$ & 1.26 & & \\
\hline & $4+$ & 1.25 & & \\
\hline & $5+$ & 1.15 & & \\
\hline & $6+$ & 1.27 & & \\
\hline & $7+$ & 1.26 & & \\
\hline \multirow{4}{*}{$\begin{array}{c}\text { Lika } \\
\text { (Treer et al. } \\
\text { 1999) }\end{array}$} & $1+$ & 0.90 & \multirow{4}{*}{2.670} & \multirow{4}{*}{ I } \\
\hline & $3+$ & 0.98 & & \\
\hline & $4+$ & 0.94 & & \\
\hline & $5+$ & 1.12 & & \\
\hline \multirow{5}{*}{$\begin{array}{c}\text { Kupa } \\
\text { (Treer et al. } \\
\text { 1999) }\end{array}$} & $1+$ & 0.97 & \multirow{5}{*}{3.240} & \multirow{5}{*}{ I } \\
\hline & $2+$ & 1.03 & & \\
\hline & $3+$ & 1.08 & & \\
\hline & $4+$ & 1.25 & & \\
\hline & $5+$ & 1.15 & & \\
\hline \multirow{5}{*}{$\begin{array}{c}\text { Lonja } \\
\text { (Treer et al. } \\
\text { 1999) }\end{array}$} & $0+$ & 1.36 & \multirow{5}{*}{2.875} & \multirow{5}{*}{ I } \\
\hline & $1+$ & 1.26 & & \\
\hline & $2+$ & 1.20 & & \\
\hline & $4+$ & 1.10 & & \\
\hline & $5+$ & 1.11 & & \\
\hline
\end{tabular}

\section{Conclusion}

The fish in age classes $1+, 4+$ and $5+$ show positive allometric growth and negative allometric growth is observed in age classes $2+\mathrm{i} 3+$. Based on the conducted research, it can be concluded that the analyzed individuals of the chub have more intensive growth in length during the ages of $2+$ and $3+$, and after that the individuals begin to gain more weight in relation to their body length. The condition factor in all age classes was approximately 1 and the highest value of this factor was determined in age class 5+. There are no statistically significant differences of the condition factor of chub of the same age class from different localities.

\section{References}

[1]. Bajrić, A., Adrović, A., Hajdarević, E., Skenderović, I., \& Tanović, E. (2018). Body pigmentation and meristic characteristics of Balkan golden loach (Sabanejewia balcanica) from the water catchment area of the river Sava. Croatian Journal of Fisheries, 76(2), 72-79. DOI: 10.2478/cjf-2018-0009

[2]. Byers, J. E., Reichard, S., Randall, J. M., Parker, I. M., Smith, C. S., Lonsdale, W. M., ... \& Hayes, D. (2002). Directing research to reduce the impacts of nonindigenous species. Conservation Biology, 16(3), 630-640.

[3]. Sedaghat, S., Ahangari, W. D. P., Arabi, M. H., Rahmani, H., \& Vatandoost, S. (2012). Age and Growth of Chub, Squalius cephalus (Bonaparte, 1837). Gamasiab River of the Hamadan Province, Iran. World Journal of Fish and Marine Sciences, 4(6), 550-553.

[4]. Hänfling, B., \& Brandl, R. (1998). Genetic and morphological variation in a common European cyprinid, Leuciscus cephalus within and across Central European drainages. Journal of Fish Biology, 52(4), 706-715.

[5]. Berg, L. S. (1949). Freshwater fishes of the USSR and adjacent countries. Israel program for scientific translations, Jerusalem, 2, 496.

[6]. Sofradžija, A. (2009). Slatkovodne ribe Bosne i Hercegovine. Vijeće kongresa bošnjačkih intelektualaca, Sarajevo, 1-150.

[7]. Ricker, W. E. (1975). Computation and interpretation of biological statistics of fish populations. Bull. Fish. Res. Bd. Can., 191, 1-382.

[8]. SOKAL, R.R. and ROHLF, F.J., (1997). Biometry: The Principles and Practice of Statistics in Biological Research, , 3rd edn., New York: Freeman..

[9]. Koc, H. T., Erdogan, Z., Tinkci, M., \& Treer, T. (2006). Age, growth and reproductive characteristics of chub, Leuciscus cephalus (L., 1758) in the Ikizcetepeler dam lake (Balikesir), Turkey. J. Appl. Ichthyol, 1, 6.

[10]. Benzer, S. (2013). Age and growth of chub [Squalius Cephalus (L., 1758)] population in kirmir stream of sakarya river, Turkey. Indian Journal of Animal Research, 47(6), 538-542.

[11]. Vlach, P., Dušek, J., Švátora, M., \& Moravec, P. (2005). Growth analysis of chub, Leuciscus cephalus (L.), and dace, Leuciscus leuciscus (L.), in the Úpoř stream using growth data of recaptured marked fish. Czech J Anim Sci, 50(7), 329-339.

[12]. Treer, T., Habeković, D., Safner, R., Kolak, A., \& Aničić, I. (1999). Length-mass relationship in chub (Leuciscus cephalus) from five Croatian rivers. Agriculturae Conspectus Scientificus, 64(2), 137-142.

[13]. Bajrić, A., Hajdarević, E., Adrović, A., \& Skenderović, I. (2020). Uzrast i rast klijena (Squalius cephalus) iz voda sjeveroistočne Bosne. Educa, 13. 